Review

\title{
Symbiotic Plant Biomass Decomposition in Fungus-Growing Termites
}

\author{
Rafael R. da Costa ${ }^{1}$ (), Haofu Hu ${ }^{1}$, Hongjie $\mathrm{Li}^{2}$ and Michael Poulsen ${ }^{1, *(1)}$ \\ 1 Section for Ecology and Evolution, Department of Biology, University of Copenhagen, \\ Universitetsparken 15, 2100 Copenhagen East, Denmark; rafael.dacosta@bio.ku.dk (R.R.d.C.); \\ haofu.hu@bio.ku.dk (H.H.) \\ 2 Department of Bacteriology, University of Wisconsin-Madison, Madison, WI 53706, USA; hli555@wisc.edu \\ * Correspondence: mpoulsen@bio.ku.dk; Tel.: +45-3533-0377
}

Received: 1 February 2019; Accepted: 6 March 2019; Published: 28 March 2019

\begin{abstract}
Termites are among the most successful animal groups, accomplishing nutrient acquisition through long-term associations and enzyme provisioning from microbial symbionts. Fungus farming has evolved only once in a single termite sub-family: Macrotermitinae. This sub-family has become a dominant decomposer in the Old World; through enzymatic contributions from insects, fungi, and bacteria, managed in an intricate decomposition pathway, the termites obtain near-complete utilisation of essentially any plant substrate. Here we review recent insights into our understanding of the process of plant biomass decomposition in fungus-growing termites. To this end, we outline research avenues that we believe can help shed light on how evolution has shaped the optimisation of plant-biomass decomposition in this complex multipartite symbiosis.
\end{abstract}

Keywords: carbohydrate-active enzymes; Blattodea; Macrotermitinae; microbiota; social insects; Termitomyces

\section{Introduction}

\subsection{Plant Substrate Use as Main Nutrient Source}

Plant biomass is the largest carbon reservoir on Earth and is used by a wide range of different organisms as a main food source [1]. A barrier in gaining nutrients from plant material is the inability of most animals to process plant biomass, due to the complexity of the plant cell wall [1], composed primarily of cellulose, hemicellulose, pectin and lignin [2]. The plant cell walls form a barrier to nutrient acquisition, and depending on the developmental stage [3], plant species [4], and degree of decomposition [5], structural components change in abundance. Breaking down this structural heterogeneity requires enzymatic, chemical, and/or mechanical reactions [5-8]. The enzymes for the breakdown, biosynthesis and modification of glycoconjugates, di-, oligo- and polysaccharides, are known as Carbohydrate-Active enZymes (CAZymes) [9]. No living organism has the complete metabolic reservoir necessary to convert plant cell wall components into nutrients [1]. To overcome this challenge, many organisms obtaining their nutrition from plant biomass engage in symbioses with diverse lignocellulolytic microorganisms [10-14].

\subsection{Termites Have Relied on Symbiotic Digestion of Lignocellulose for Millions of Years}

Among the insects, termites have achieved an outstanding ecological success, with more than 3000 extant species in 281 genera and eight families [15-18] that are widely distributed around the globe, including in tropical, subtropical and warm temperate regions. Termites evolved from a cockroach ancestor (Blattodea) [17] and are broadly divided into the lower (families: Mastotermitidae, Stolotermitidae 
Hodotermitidae, Archotermopsidae, Kalotermitidae, Serritermitidae and Rhinotermitidae) and higher (family: Termitidae) termites based on the respective presence or absence of intestinal flagellates [19,20].

Termites ingest lignocellulosic substrates at different degrees of decomposition [16,21] and have been classified in feeding groups based on their substrate use: Group I: lower termites feeding on wood, grass, and litter; Group II: higher termites feeding on wood, grass, and litter, including the fungus feeders (Macrotermitinae) in the sub-group IIF; Group III: highly-degraded wood and soil with a high organic content; and Group IV: the true soil-feeders [22]. Termites are among the few animals capable of producing endogenous cellulolytic enzymes [23,24], but this capacity alone is insufficient to decompose plant biomass [1]. Thus, they rely on their symbiotic gut microflora to depolymerize lignocellulose with subsequent fermentation, resulting in the production of short-chain fatty acids that can be oxidized by the host $[25,26]$.

The wood-feeding lower termites associate with cellulolytic flagellates and gut bacteria, of which the most abundant are in the phyla Spirochaetes and Proteobacteria $[25,27,28]$. Approximately 60 million years ago (MYA), the ancestor of the higher termites lost the gut flagellates $[29,30]$ and associated with an almost exclusively bacterial gut microbiota [31-33]. Spirochaetes, Fibrobacteres, and members of the TG3 phylum dominate higher termites feeding on sound wood or grass, while humus, soil, and fungus feeders have more similar gut communities, dominated by Firmicutes, Bacteroidetes and Proteobacteria [34]. However, they differ in the abundance of Spirochaetes, which is lower in soil feeders and almost absent in the fungus feeders [34].

Approximately 30 MYA, the higher termite subfamily Macrotermitinae engaged in an obligate co-dependent mutualism with basidiomycete fungi in the genus Termitomyces (Agaricomycetes, Lyophyllaceae) [35-37]. Fungus-growing termites comprise 11 genera with approximately 330 described species [33,35] that associate with ca. 40 described Termitomyces species $[37,38]$. In addition to the mutualism with Termitomyces, the termites maintain complex gut microbial communities [32,34,39-42]. The evolution of fungiculture involved the consequential origin of a dual decomposition strategy with complementary contributions to plant-biomass decomposition between the externally-maintained fungal gardens and bacterial contributions during two gut passages (Figure 1). This strategy appears to have allowed the subfamily to obtain near-complete decomposition of plant biomass, possibly contributing to their dominance as decomposers in the ecosystems they inhabit $[5,43]$.

\section{The Tripartite Fungus-Growing Termite Symbiosis}

\subsection{The Symbiosis Between Fungus-Growing Termites and Termitomyces}

Prospective queens and kings are produced in mature nests. Then, during the mating flight, they leave their natal nests, pair-up, shed their wings and dig into the ground to establish a new colony [36]. Shortly thereafter, they begin to produce the first cohort of workers, who feed on soil and build pillars comprised of faecal pellets [44-46]. These first foragers also collect plant substrate, first turning these pillars greenish and a few days later they will be covered in Termitomyces hyphae $[44,45,47]$. Workers thus appear to obtain Termitomyces spores when foraging for plant substrates [48] and these spores are released into the environment from fruiting bodies (mushrooms) on mature nests [37,49]. This means that the transmission of Termitomyces is predominantly horizontal (environmental acquisition), but two exceptions to this pattern exist: the termite species Macrotermes bellicosus and the genus Microtermes transmit Termitomyces vertically (from parent to offspring colonies) [37,48,50].

The established fungus gardens appear as a cork-like structure termed the "fungus comb". This comb is composed of termite primary faeces, which is a blend of plant material and asexual Termitomyces spores that pass through the guts of young workers [51] (Figure 1). The termites provide the fungal symbiont with optimal growth conditions (e.g., controlled temperature and humidity and inhibition of other fungi), and constant inoculation of plant substrate [52]. In return, Termitomyces decomposes plant material that cannot be digested by the termites themselves and provides nutrient-rich nodules formed by a conglomerate of conidiospores [47,51] (Figure 1). 


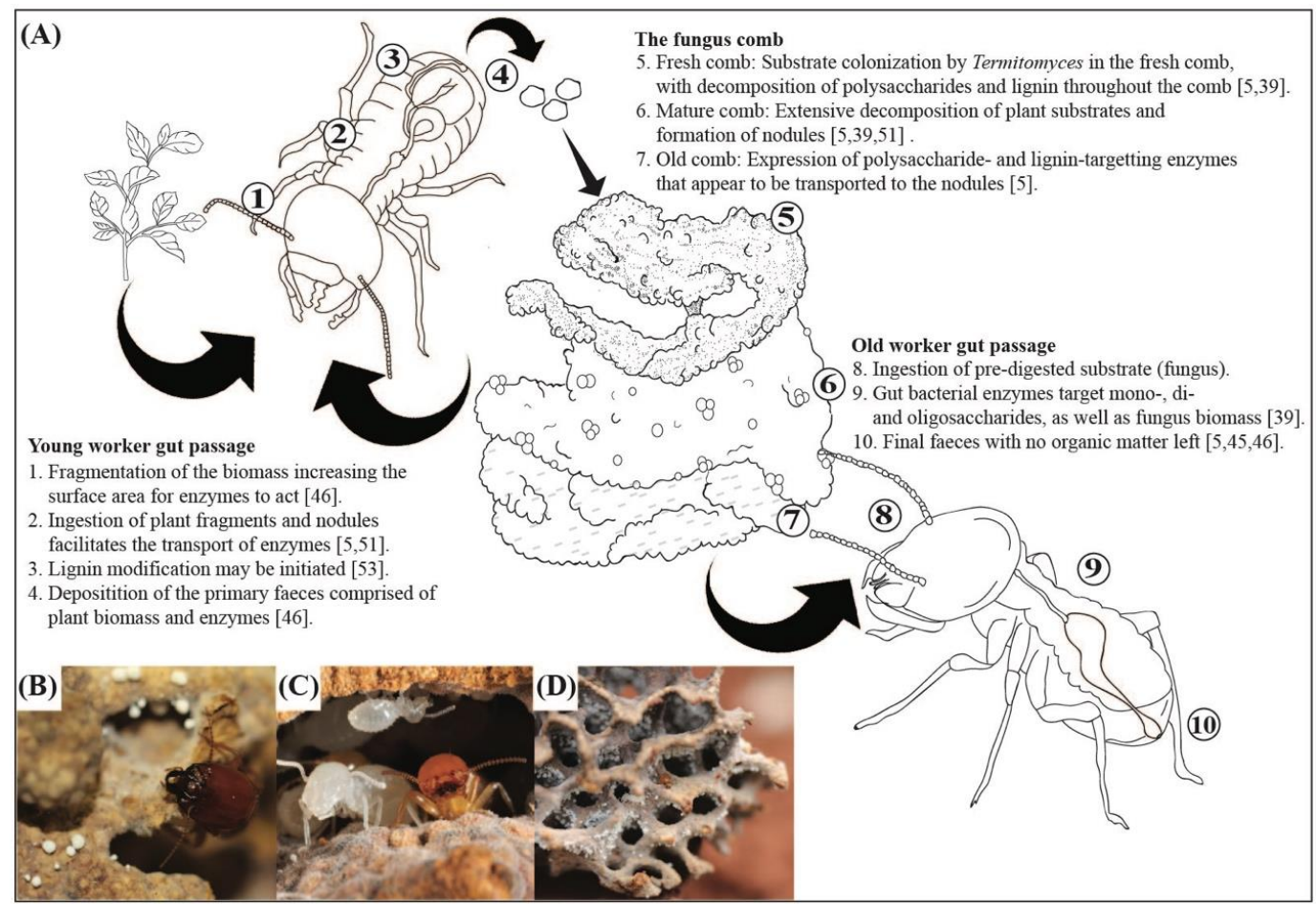

Figure 1. (A) The process of plant biomass incorporation and symbiotic complementary decomposition in the fungus-growing termites Macrotermes and Odontotermes species [5,46,51,53]. (B): Macrotermes natalensis soldier and nodules within the fungus comb (photo by M.P.). (C) Macrotermes bellicosus nymphs and workers in the fungus comb (photo by Nicky P.M. Bos). (D) Odontotermes sp. fungus comb with workers (photo by M.P.).

Despite predominant horizontal transmission, phylogenetic analyses of Macrotermitinae and Termitomyces indicate some degree of interaction specificity, i.e., species of termites are restricted to associate with certain Termitomyces species [37]. At lower levels, specificity differences also remain; e.g., Macrotermes natalensis colonies associate with a single biological species of Termitomyces, whereas individual Odontotermes species may associate with several Termitomyces species [54-57]. Geographical isolation, synchronised dispersal of winged reproductives [56], and substrate use have been proposed to help explain these patterns [57-59]. Specificity in the light of horizontal transmission might appear counterintuitive, as vertical transmission often leads to a higher degree of interaction specificity and co-evolution [60]. However, it is often observed that traits of a symbiont are lost because their functions become redundant if the other partner reliably provides the resources $[61,62]$. This bilateral specialization between symbionts favours obligate associations, potentially leading to co-cladogenesis even in the absence of vertical transmission [56], as appears to be the case of the Macrotermitinae-Termitomyces association [37,51].

\subsection{The Symbiosis between Fungus-Growing Termites and Gut Bacteria}

The external primary decomposition of plant material in fungus gardens substantially changed the need for internal cellulose digestion, reflected in the marked difference between the gut microbiota of other higher termites and the fungus-growing termites, who host gut bacteria with reduced capacity for digestion of cellulose and other complex polysaccharides $[39,63]$. The possible roles of gut bacteria in fungus-growing termites include decomposition of other parts of the ingested plant substrates [32,39,63,64], inhibition of pathogens [65], amino acid synthesis [66], and nitrogen fixation $[64,67]$. The guts of fungus-growing termites also have a greater abundance of enzymes targeting chitin $[39,64,68]$ and other fungal cell wall components $[39,63,68]$, possibly in part contributed by the bacteria dominating fungus-growing termite guts $[39,63,67]$. 
Since fungus-growing termite species have many traits in common (e.g., plant substrate processing and a fungal diet), it is unsurprising that many bacterial taxa are shared across fungus-growing termite genera [42,69-71]. This 'core' microbiota is dominated by Bacteroidetes and Firmicutes and is more similar to cockroach gut communities than to those of most other termites [69-72]. Within colonies, gut microbial assemblies can also reflect specific termite colony member roles, with quantitative differences in bacterial relative abundances between castes and ages of workers and soldiers [41,42,73]. The most divergent microbiota is those in queens and kings, which are greatly reduced in bacterial diversity compared to workers and soldiers, being dominated by a few bacteria that are absent or only present in very low abundances in sterile (non-reproducing) castes $[39,42,43,69]$. This suggests that if male and/or female alates bring the bacterial inocula for the first workers in incipient nests, most of these are lost as the royal pair matures, likely due to changes in bacterial roles and the royal pair diet [42].

\subsection{Substrate Use by Different Fungus-Growing Termite Species}

Fungus-growing termites play important roles in recycling of nutrients in their environments. Macrotermitinae may harvest $20 \%-30 \%$ of the annual litter production and up to $65 \%$ of dry litter, while $80 \%$ of the carbon ingested by the Macrotermitinae may be digested by Termitomyces [74]. In some arid tropical environments, fungus-growing termites may recycle up to $90 \%$ of all dead plant material [75], benefitting natural ecosystems [76], but also causing serious damage and economical loss in agriculture [77-82].

Figure 2 provides an overview of known substrate use from studies on fungus-growing termite species in natural and in agricultural areas (for a full list, see Table S1). Based on this, fungus-growing termites are best-characterised as generalists $[18,83,84]$, with wood and grass being the most frequently used substrates. However, some termite species may preferentially forage on certain substrate types [85]. The size of plant biomass fragments [85] and seasonal variation [37] may also affect foraging preferences, which could also be driven by plant community composition affecting substrate availability. For example, fungus combs of Macrotermes michaelseni in Kenya were composed of $30 \%$ wood and $70 \%$ grass in one area and $64 \%$ wood and $36 \%$ herbaceous species in another area [84]. Such geographic variation suggests dietary flexibility, which may well contribute to termite abundance and their prominent role in nutrient recycling in African savannah ecosystems.

\subsection{Plant Biomass Processing and Breakdown}

The major components of plant cell walls, cellulose, hemicellulose, and lignin require mechanical, enzymatic or chemical reactions to break. Cellulose is a polymer of glucose linked with $\beta-1-4$ bonds and three types of enzymes are needed for its complete degradation: endo-cellulases cut the long cellulose chains into smaller chains, thereby forming ends that exo-cellulases can act on [24]. Exo-cellulases cleave to form disaccharides (cellobiose) from the longer cellulose chains, and cellobiases or glucosidases cleave this cellobiose into glucose, which can be taken up and utilised by the organism [24]. In contrast to recalcitrant cellulose, hemicelluloses are more easily hydrolysed either chemically or enzymatically and many enzymes (hemicellulases) contribute to doing so [24]. Lignin is a complex of phenolic rings, which are very difficult to cleave, leaving only white-rot fungi and some bacteria able to do so [24]. These organisms employ oxidizing enzymes (peroxidases and laccases) that create chain reactions, turning the aromatic rings into reactive free radicals [86]. Lignin does not contain nitrogen and the process likely also does not generate much energy, so cleaving lignin is likely mainly to improve access to the cellulose and any nitrogen within in the woody substrate $[24,86]$.

Efficient plant biomass processing and decomposition in the fungus-growing termite symbiosis involve intricate steps across space (different locations within colonies) and time (different stages of biomass break down), including enzyme contributions from all partners in the symbiosis $[39,63]$ (Figure 1). The enzymes involved in this breakdown have been the focus of many studies over the past decades; however, it remains unclear how generalisable these patterns are and how 30 million years of (co)evolutionary change has impacted patterns of symbiotic complementarity. 
Differences in CAZyme profiles and expression across Termitomyces species are likely primarily driven by what is coded for in their genomes or what is required at a given point in time, i.e., dependent on what substrates the termites harvest. Johjima et al. [87] identified a wide range of CAZymes in Macrotermes gilvus-associated Termitomyces and found that most of these enzymes were pectin degrading, suggesting that foraging by Macrotermes gilvus on mainly fresh plant material influences the fungal symbiont enzyme potential and/or expression. Consistent with this assertion, da Costa et al. [5] found high expression of cellulases, laccases, and some hemicellulases in Termitomyces from M. natalensis and Odontotermes sp. foraging on dead plant material and animal dung [5].
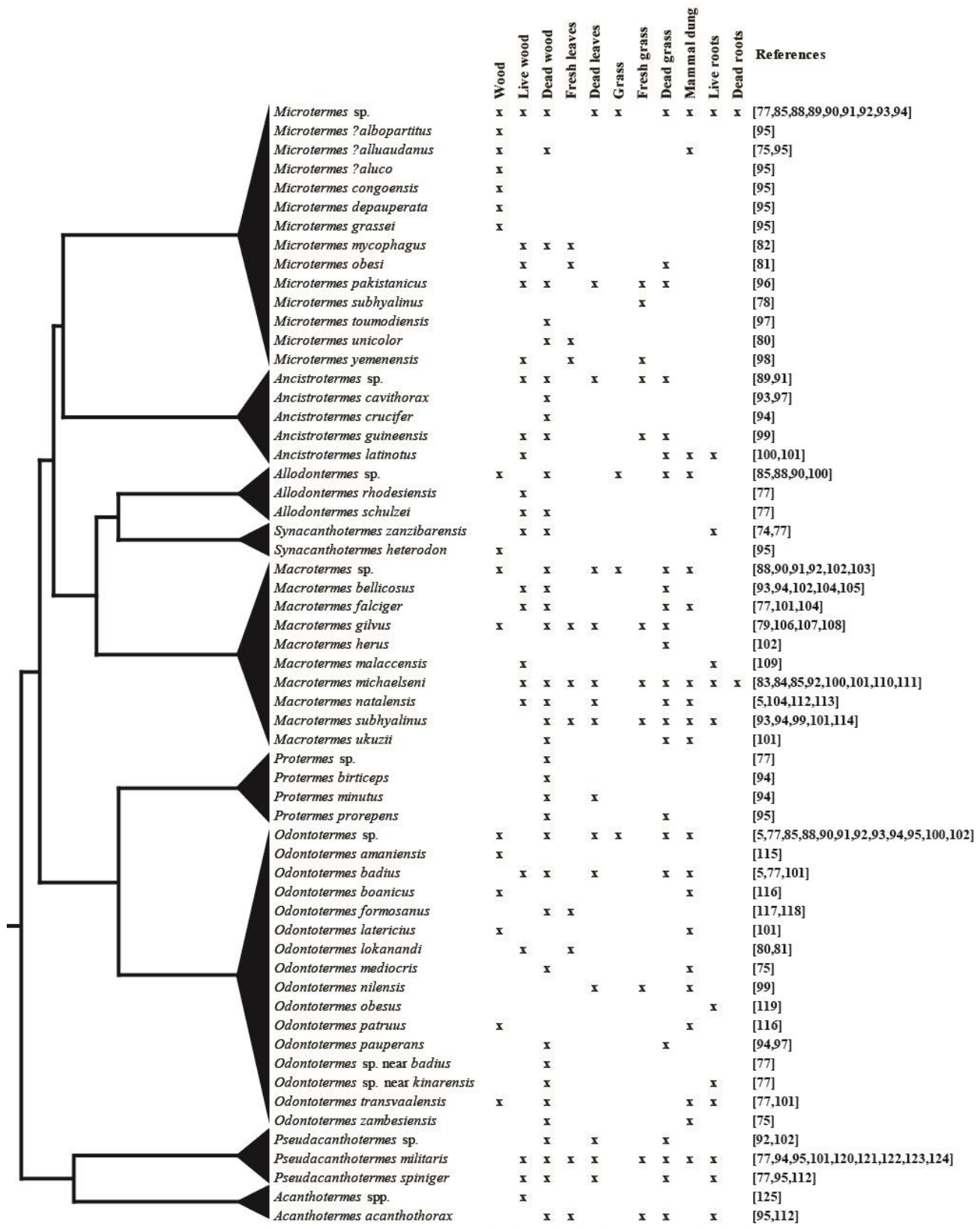

Figure 2. Forage substrate use by fungus-growing termites found in the literature (for a full list of all references and their reported findings, see Table S1 [5,74,75,77-85,88-125]) mapped on a schematic phylogeny of the subfamily [35]. Species given the same species name or labelled sp. or spp. in the original reports were grouped for clarity. The last columns "Wood" and "Grass" give cases where authors only mention forage substrate but not whether the plant material was alive or dead. The annotations "?" or "near" were not explained in the original reports, and the species were, therefore, treated as unique here. 
Lignin breakdown in the symbiosis has also received attention without reaching a clear conclusion about how generalisable the process is across termite and fungal species. Termitomyces associated with M. bellicosus decomposes lignin to facilitate termite access to cellulose [87,126], but laccase activity, presumably contributing to lignin cleavage, has only been found in Termitomyces fungus combs associated with some (e.g., Microtermes sp., Odontotermes sp., and Macrotermes gilvus) but not other (Odontotermes longignathus and Hypotermes sp.) termite species [126]. An active laccase has further been proposed to be insufficient to cleave lignin, as the enzyme is unable to oxidise lignin by itself [87], but RNAseq from M. natalensis and Odontotermes spp. found that several enzymes targeting lignin can be present and expressed in at least Termitomyces species associated with these termite species [5]. The breakdown of lignin may also be complemented by chemical reactions during the first gut passage [53]. Given that specific cleavage and removal of lignin has been documented in wood feeders $[127,128]$, it may not be surprising that the fungus-growing termite symbiosis depolymerizes lignin structures, even though only a few lignin-targeting bacterial enzymes have been identified in the termite gut $[39,68]$.

The roles of gut bacteria in plant decomposition may vary with different termite-fungus-bacteria combinations, possibly in ways where the collective assembly of symbionts complements each other enzymatically. Liu et al. [64] identified xylanases and $\beta$-glucosidases from gut bacteria in $M$. annandalei and later complemented this with next-generation sequencing technologies on O. yunnanensis to identify a broad array of CAZyme genes [63]. These analyses suggested that a large portion of the bacteria-derived enzymes target oligosaccharides, which was corroborated in a comparison of M. natalensis and O. yunnanensis gut metagenomes with the dung-feeding termite Amitermes wheeleri and two Nasutitermes spp. (wood-feeders) $[129,130]$. The results indicate that enzymes targeting complex plant polysaccharides are relatively low in abundance in fungus-growing termite gut bacteria, while enzymes targeting oligosaccharides are relatively more abundant [39]. The enzymatic capacity of Termitomyces to degrade complex polysaccharides could thus be complemented by gut bacterial enzymes [39].

More recently, da Costa [5] compared the enzyme diversity and activity in nodules, worker guts, fresh and old comb in M. natalensis and two Odontotermes species and complemented this with RNAseq from nodules, fresh and old comb. A wide range of enzymes was identified, with the highest activity and expression being of cellulases and hemicellulases, and comparable nodule and worker gut enzyme activities suggest that enzymes within nodules remain active during gut passage [5]. After normalization of enzyme activities (i.e., enzyme activity/fungal biomass), old workers were most similar to old comb in their expression and young workers most similar to nodules and fresh comb, mirroring what differently-aged workers eat (Figure 1). Although enzyme activity was higher in nodules and fresh comb than old comb, fungus comb RNAseq suggested that the highest expression of these enzymes is in the old comb. This may imply that enzymes are produced in the mature older parts of the comb and transported to the nodules via Termitomyces hyphae, allowing for transfer through worker guts to the fresh comb, where the enzymes are needed to cleave components in the freshly-incorporated plant substrate (Figure 1). This supports the "ruminant hypothesis" by Nobre and Aanen [58], who hypothesised that Termitomyces could use the first gut passage to efficiently move lignocellulosic enzymes from mature to fresh parts of the fungus comb.

\section{Research Avenues to Improve Our Understanding of the Evolution of Ancient Symbiotic Plant Biomass Decomposition}

Fungus-growing termites manage an elaborate tripartite symbiosis that appears to have overcome major challenges for efficiently utilizing plant biomass. The termites process and provide their microbial symbionts with substrate, and these microbial partners offer the genetic machinery necessary for complete utilisation of plant substrates. While recent years have provided many novel insights, our understanding of how evolution has shaped the optimisation of plant-biomass decomposition is still lacking in many aspects. Albeit not an exhaustive list, we believe that the set of research avenues 
we outline below will be important to improve our understanding of the fungus-growing termite symbiosis specifically and complex symbioses more broadly.

\subsection{How has 30 Million Years of Evolution Altered Symbiotic Contributions to Plant-Biomass Decomposition?}

We lack a fundamental understanding of differences in plant-biomass decomposition potential across different Termitomyces species, and how such differences may be complemented by different contributions from gut bacteria. Currently, we lack information from the vast majority of the ca. 40 described Termitomyces species, and comparative analyses of their genomes paired with metagenome studies on gut bacteria symbionts would allow for insights into the co-evolutionary patterns of CAZyme provisioning and division of symbiont labour in the symbiosis.

\subsection{Improving Our Understanding of the Link between Enzyme Targets and the Producing Organisms}

A major challenge in understanding functions within complex symbiont communities is assigning symbiont identities to roles. This is less problematic for the monoculture Termitomyces fungus maintained by the termites but challenging for the bacterial communities $[34,41,42,69,70]$. High-quality gut metagenomes would allow for better assemblies and binning of bacteria OTUs. This could be coupled with bioinformatic predictions of putative functions with e.g., Peptide Pattern Recognition [131,132], which uses binding-site identification from sequences to improve predicted enzyme functions. This could both help establish gut bacteria functions and clarify whether variation in gut bacteria community composition between termite species is relevant to plant biomass processing and division of labour between the termites, fungal symbiont, and gut bacteria.

\subsection{How Variable Is Substrate Use across Termite Species}

Our current understanding of substrate use is restricted to very broad categories (e.g., wood, grass, etc.) without the identification of plant species harvested (Figure 2). DNA metabarcoding of environmental DNA [133] could be employed on termite guts and fungus combs to establish what plant families, genera, and even species, termites forage on. This would allow us to establish whether generalist substrate use is the norm and differences merely reflect plant availability in the environment or if preferences indeed exist. Laboratory experiments providing the termites with various plant species or biomass at different degrees of decomposition could complement this to elaborate any termite preferences. Insights from such work could help inform how foraging affects processes on ecological (e.g., impacts on the environment) and evolutionary (e.g., how the adoption of new diets may shape ecological traits) time scales.

\subsection{How Flexible Is Enzyme Production in Fungus-Growing Termite-Associated Symbionts?}

Substrate preferences between termite species/genera could lead to specialisation in enzymatic machineries. Alternatively, enzyme production could be plastic depending on plant species availability and seasonality. These alternative hypotheses could be explored by coupling substrate preference determination with enzyme assays (e.g., chromogenic substrates, AZCL, lignin-degrading enzyme assays [5,134-136]) and symbiont CAZyme gene expression in fungus combs and termite guts after termite foraging on different substrates, either in natural environments over geographical locations with different plant communities or through laboratory experimentation.

\subsection{How Do Caste Roles and Caste-Specific Symbionts Interact to Affect Decomposition?}

Social insect castes based on individual age and size are important for colony function and the integration and decomposition of plant biomass. As elucidated above, gut microbial community compositions differ between fungus-farming termite castes [41,42,70], but the causal reasons for these differences are as of yet largely unclear. They may merely be driven by differences in diet between castes (workers eat plant substrate, while soldiers and reproductives do not), which could select 
for different bacteria to flourish within guts or lead to differences in bacterial contributions to the breakdown of dietary components. Alternatively, community differences may imply that different bacteria serve important functions that affect caste roles, such as aiding lignin cleavage in workers [53] or contributing to defensive compounds in soldiers. Work that can shed light on bacterial functions within gut communities thus has the potential to aid our understanding of the role of symbionts in a social evolution context.

\subsection{Do Differences in Substrate Use Align with the Interaction Specificity between Termite Host and Symbionts?}

The importance of substrate use for patterns of interaction specificity between the termites and Termitomyces could be tested by providing laboratory colonies with filter paper containing spores from multiple Termitomyces strains and/or even species. If the termites select their 'normal' symbiont in the presence of multiple symbionts, substrate type may not be the only factor of importance for interaction specificity. Providing the termites with different plant substrates containing spores of non-native symbionts could help establish whether termite species with high degrees of interaction specificity with Termitomyces could establish association with new symbionts, or whether adaptations and specificity preclude that such novel associations arise [44].

\subsection{Does Fenton Chemistry Play a Role in Lignin Depolymerization?}

Fenton chemistry (the Fenton reaction) is a process in which hydrogen peroxide $\left(\mathrm{H}_{2} \mathrm{O}_{2}\right)$ in the presence of e.g., soluble iron is split to generate water and hydroxyl radicals ( $\mathrm{OH}-$ a reactive oxygen species that is a strong oxidizing agent). Non-enzymatic Fenton chemistry has been identified in other insect [137] and lower-termite [100] guts, where it has been proposed to play a role in gut-mediated lignocellulose breakdown. Several Auxiliary Activity (AA) families that could initiate Fenton reactions have been identified in Termitomyces RNAseq data [5] and in a M. natalensis gut metagenome [138], suggesting the potential for such reactions being of importance. Establishing whether this indeed is the case would be an exciting research avenue to further improve our understanding of the role of Fenton reactions in lignin depolymerization.

\section{Conclusions}

Recent opportunities in -omics approaches have provided substantial and novel insights to symbiont roles in plant biomass decomposition in fungus-growing termites. A number of pioneering studies have determined broad substrate use, suggesting that farming termites are generalist rather than host plant-specific. However, work that goes beyond characterisations of substrate use in these broad categories (wood, grass, etc.) could help shed light on cryptic specificities. Understanding substrate use would allow us to better evaluate the role of fungus-farming termites in nature, and to establish if substrate use plays a role in governing termite-symbiont association specificities.

The symbionts associated with the farming termites do not per se appear to differ substantially from other plant-biomass degrading microbes, suggesting that it is rather the integration of the external fungal comb and internal gut passages than novel enzymes for plant biomass decomposition that enable the symbiosis to digest plant polysaccharides. This makes the symbiosis interesting to compare to other plant biomass decomposition systems/symbioses (e.g., the cow rumen), which would allow us to establish how alternative strategies for efficient decomposition have been optimised by natural selection.

The patterns of specificity over the long evolutionary history of the association provide excellent opportunities for comparative analyses of substrate use and plant biomass decomposition. This also applies to the contributions of enzymes from fungal and bacterial symbionts, which currently suffer from being biased towards a few termite species, being focused on either bacterial communities or Termitomyces in isolation, and often overlooking termite enzyme contributions. A more holistic approach with comparative analyses of all partners in a (co)evolutionary context across phylogenies, 
geography, and habitats would improve our understanding of both individual symbiont assemblies and the evolutionary histories of conserved and derived plant-biomass decomposition strategies.

Supplementary Materials: The following are available online at http:/ /www.mdpi.com/2075-4450/10/4/87/s1, Table S1: Studies that have reported forage substrates in fungus-growing termite species, summarized in Figure 2 of the main text. Species names are given as reported in the respective references. The references Eggleton et al. [1] and Nkunika [2] did not explain what the taxonomical annotations 'near' and '?' mean in their studies.

Author Contributions: Conceptualization, R.R.d.C., H.H., and M.P.; Writing-Original draft preparation, R.R.d.C. and H.H.; Writing—Review and Editing: all authors; Visualization: R.R.d.C.; Funding Acquisition: M.P.

Funding: This work was funded by the Department of Energy Great Lakes Bioenergy Research Center Office of Science Grant DE-FC02-07ER64494 (H.L.) and a Villum Kann Rasmussen Young Investigator Fellowship (VKR10101) to M.P.

Acknowledgments: We thank Justinn Hamilton, Veronica M. Sinotte, Nicky P. M. Bos, Benjamin H. Conlon, Morten Schiøtt, and Kasun H. Bodawatta for valuable comments on the manuscript, and Nicky P. M. Bos for permission to use the photo in Figure 1c.

Conflicts of Interest: The authors declare no conflict of interest.

\section{References}

1. Pauly, M.; Keegstra, K. Cell-wall carbohydrates and their modification as a resource for biofuels. Plant J. 2008, 54, 559-568. [CrossRef] [PubMed]

2. McNeil, M.; Darvill, A.G.; Fry, S.C.; Albersheim, P. Structure and functional of the primary cell walls of plants. Annu. Rev. Biochem. 1984, 53, 625-663. [CrossRef] [PubMed]

3. Rancour, D.M.; Marita, J.M.; Hatfield, R.D. Cell wall composition throughout development for the model grass Brachypodium distachyon. Front. Plant Sci. 2012, 3, 266. [CrossRef] [PubMed]

4. Pettersen, R.C. Wood sugar analysis by anion chromatography. J. Wood Chem. Technol. 1991, 14, $495-501$. [CrossRef]

5. Da Costa, R.R.; Hu, H.; Pilgaard, B.; Sabine, S.M.; Schückel, J.; Pedersen, K.S.K.; Kračun, S.K.; Busk, P.K.; Harholt, J.; Sapountzis, P.; et al. Enzyme activities at different stages of plant biomass decomposition in three species of fungus-growing termites. Appl. Environ. Microbiol. 2018, 84, e01815-17. [CrossRef]

6. Burton, R.A.; Fincher, G.B. $(1,3 ; 1,4)-\beta$-D-glucans in cell walls of the Poaceae, lower plants, and fungi: A tale of two linkages. Mol. Plant 2009, 2, 873-882. [CrossRef]

7. Taylor, N.G. Cellulose biosynthesis and deposition in higher plants. New Phytol. 2008, 178, 239-252. [CrossRef]

8. Ishii, S. Cell Wall Cementing materials of grass leaves. Plant Physiol. 1984, 76, 959-961. [CrossRef]

9. Zhao, Z.; Liu, H.; Wang, C.; Xu, J.R. Comparative analysis of fungal genomes reveals different plant cell wall degrading capacity in fungi. BMC Genom. 2013, 14, 274. [CrossRef]

10. Smant, G.; Stokkermans, J.P.W.G.; Yan, Y.; de Boer, J.M.; Baum, T.J.; Wang, X.; Hussey, R.S.; Gommers, F.J.; Henrissat, B.; Davis, E.L.; et al. Endogenous cellulases in animals: Isolation of -1,4-endoglucanase genes from two species of plant-parasitic cyst nematodes. Proc. Natl. Acad. Sci. USA 1998, 95, 4906-4911. [CrossRef]

11. Suen, G.; Scott, J.J.; Aylward, F.O.; Adams, S.A.; Tringe, S.G.; Pinto-Tómas, A.A.; Foster, C.E.; Pauly, M.; Weimer, P.J.; Barry, K.W.; et al. An insect herbivore microbiome with high plant biomass-degrading capacity. PLoS Genet. 2010, 6, e1001129. [CrossRef] [PubMed]

12. Leschine, S.B. Cellulose degradation in anaerobic environments. Annu. Rev. Microbiol. 1995, 49, $399-426$. [CrossRef] [PubMed]

13. Stanley, D.; Denman, S.E.; Hughes, R.J.; Geier, M.S.; Crowley, T.M.; Chen, H.; Haring, V.R.; Moore, R.J. Intestinal microbiota associated with differential feed conversion efficiency in chickens. Appl. Microbiol. Biotechnol. 2012, 96, 1361-1369. [CrossRef] [PubMed]

14. Brulc, J.M.; Antonopoulos, D.A.; Berg, M.E.; Wilson, M.K.; Yannarell, A.C.; Dinsdale, E.A.; Edwards, R.E.; Frank, E.D.; Emerson, J.B.; Wacklin, P.; et al. Gene-centric metagenomics of the fiber-adherent bovine rumen microbiome reveals forage specific glycoside hydrolases. Proc. Natl. Acad. Sci. USA 2009, 106, 6-11. [CrossRef]

15. Kambhampati, S.; Eggleton, P. Taxonomy and phylogenetics of Termites. In Termites: Evolution, Sociality, Symbioses and Ecology; Abe, T., Bignell, D.E., Higashi, M., Eds.; Springer: Dordrecht, The Netherlands, 2000; pp. 1-23. 
16. Eggleton, P. An introduction to termites: Biology, taxonomy and functional morphology. In Biology of Termites: A Modern Synthesis; Bignell, D., Roisin, Y., Lo, N., Eds.; Springer: Dordrecht, The Netherlands, 2010; pp. 1-26.

17. Inward, D.J.G.; Vogler, A.P.; Eggleton, P. A comprehensive phylogenetic analysis of termites (Isoptera) illuminates key aspects of their evolutionary biology. Mol. Phylogenet. Evol. 2007, 44, 953-967. [CrossRef]

18. Krishna, K.; Grimaldi, D.A.; Krishna, V. Introduction. In Treatise on the Isoptera of the World; Krishna, K., Grimaldi, D.A., Krishna, V., Engel, M.S., Eds.; American Museum of History: New York, NY, USA, 2013; pp. 1-200. ISBN 1530-7085.

19. Bourguignon, T.; Lo, N.; Cameron, S.L.; Šobotník, J.; Hayashi, Y.; Shigenobu, S.; Watanabe, D.; Roisin, Y.; Miura, T.; Evans, T.A. The evolutionary history of termites as inferred from 66 mitochondrial genomes. Mol. Biol. Evol. 2015, 32, 406-421. [CrossRef]

20. Bourguignon, T.; Lo, N.; Sobotnik, J.; Ho, S.Y.W.; Iqbal, N.; Coissac, E.; Lee, M.; Jendryka, M.M.; Sillam-Dussès, D.; Krizkova, B.; et al. Mitochondrial phylogenomics resolves the global spread of higher termites, ecosystem engineers of the tropics. Mol. Biol. Evol. 2017, 34, 597. [CrossRef]

21. Bignell, D.E. Introduction to symbiosis. In Termites: Evolution, Sociality, Symbioses, Ecology, Part 2; Abe, T., Bignell, D.E., Higashi, M., Eds.; Springer: Dordrecht, The Netherlands, 2000; pp. 189-208.

22. Donovan, S.E.; Eggleton, P.; Bignell, D.E. Gut content analysis and a new feeding group classification of termites. Ecol. Entomol. 2001, 26, 356-366. [CrossRef]

23. Scrivener, A.M.; Slaytor, M.; Rose, H.A. Symbiont-independent digestion of cellulose and starch in Panesthia cribrata Saussure, an Australian wood-eating cockroach. J. Insect Physiol. 1989, 35, 935-941. [CrossRef]

24. Cragg, M.S.; Beckham, G.T.; Bruce, N.C.; Bugg, T. D. H.; Distel, D. L.; Dupree, P.; Etxabe, A.G.; Goodell, B.S.; Jellison, J.; McGeehan, J.E.; et al. Lignocellulose degradation mechanisms across the Tree of Life. Curr. Opin. Chem. Biol. 2015, 29, 108-119. [CrossRef]

25. Brune, A. Symbiotic digestion of lignocellulose in termite guts. Nat. Rev. Microbiol. 2014, 12, 168-180. [CrossRef]

26. Breznak, J.A.; Brune, A. Role of microorganisms in the digestion of lignocellulose by termites. Annu. Rev. Entomol. 1994, 39, 453-487. [CrossRef]

27. Lo, N.; Eggleton, P. Termite phylogenetics and co-cladogenesis with symbionts. In Biology of Termites: A Modern Synthesis; Bignell, D.E., Roisin, Y., Lo, N., Eds.; Springer: Dordrecht, The Netherlands, 2011; pp. $27-50$.

28. Brune, A.; Dietrich, C. The gut microbiota of termites: Digesting the diversity in the light of ecology and evolution. Annu. Rev. Microbiol. 2015. [CrossRef]

29. Bignell, D.E.; Eggleton, P. Termites in Ecosystems. In Termites: Evolution, Sociality, Symbioses, Ecology; Abe, T., Bignell, D.E., Higashi, M., Eds.; Springer: Dordrecht, The Netherlands, 2000; pp. 363-387.

30. Ohkuma, M.; Brune, A. Diversity, structure, and evolution of the termite gut microbial community. In Biology of Termites: A Modern Synthesis; Bignell, D.E., Roisin, Y., Lo, N., Eds.; Springer: Dordrecht, The Netherlands, 2011; pp. 413-438. ISBN 9789048139767.

31. Abdul Rahman, N.; Parks, D.H.; Willner, D.L.; Engelbrektson, A.L.; Goffredi, S.K.; Warnecke, F.; Scheffrahn, R.H.; Hugenholtz, P. A molecular survey of Australian and North American termite genera indicates that vertical inheritance is the primary force shaping termite gut microbiomes. Microbiome 2015, 3, 5. [CrossRef] [PubMed]

32. Brune, A.; Ohkuma, M. Role of the termite gut microbiota in symbiotic digestion. In Biology of Termites: A Modern Synthesis; Bignell, D.E., Roisin, Y., Lo, N., Eds.; Springer: Dordrecht, The Netherlands, 2011; pp. $439-475$.

33. Hongoh, Y. Toward the functional analysis of uncultivable, symbiotic microorganisms in the termite gut. Cell. Mol. Life Sci. 2011, 68, 1311-1325. [CrossRef] [PubMed]

34. Mikaelyan, A.; Köhler, T.; Lampert, N.; Rohland, J.; Boga, H.; Meuser, K.; Brune, A. Classifying the bacterial gut microbiota of termites and cockroaches: A curated phylogenetic reference database (DictDb). Syst. Appl. Microbiol. 2015, 38, 472-482. [CrossRef] [PubMed]

35. Roberts, E.M.; Todd, C.N.; Aanen, D.K.; Nobre, T.; Hilbert-Wolf, H.L.; O'Connor, P.M.; Tapanila, L.; Mtelela, C.; Stevens, N.J. Oligocene termite nests with in situ fungus gardens from the Rukwa rift basin, Tanzania, support a paleogene African origin for insect agriculture. PloS ONE 2016, 11, 1-17. [CrossRef]

36. Korb, J.; Aanen, D.K. The evolution of uniparental transmission of fungal symbionts in fungus-growing termites (Macrotermitinae). Behav. Ecol. Sociobiol. 2003, 53, 65-71. [CrossRef]

37. Aanen, D.K.; Eggleton, P.; Rouland-Lefevre, C.; Guldberg-Frøslev, T.; Rosendahl, S.; Boomsma, J.J. The evolution of fungus-growing termites and their mutualistic fungal symbionts. Proc. Natl. Acad. Sci. USA 2002. [CrossRef] 
38. Kirk, P.M.; Cannon, P.F.; David, J.C.; Stalpers, J.A. Ainsworth \& Bigby's Dictionary of the Fungi; Kirk, P.M., Cannon, P.F., David, J.C., Stalpers, J.A., Eds.; CAB Int.: Wallingford, UK, 2011.

39. Poulsen, M.; Hu, H.; Li, C.; Chen, Z.; Xu, L.; Otani, S.; Nygaard, S.; Nobre, T.; Klaubauf, S.; Schindler, P.M.; et al. Complementary symbiont contributions to plant decomposition in a fungus-farming termite. Proc. Natl. Acad. Sci. USA 2014, 111, 14500-14505. [CrossRef]

40. Makonde, H.M.; Boga, H.I.; Osiemo, Z.; Mwirichia, R.; Mackenzie, L.M.; Göker, M.; Klenk, H.P. 16S-rRNA-based analysis of bacterial diversity in the gut of fungus-cultivating termites (Microtermes and Odontotermes species). Antonie Leeuwenhoek 2013, 104, 869-883. [CrossRef]

41. Hongoh, Y.; Ekpornprasit, L.; Inoue, T.; Moriya, S.; Trakulnaleamsai, S.; Ohkuma, M.; Noparatnaraporn, N.; Kudo, T. Intracolony variation of bacterial gut microbiota among castes and ages in the fungus-growing termite Macrotermes gilvus. Mol. Ecol. 2006, 15, 505-516. [CrossRef] [PubMed]

42. Otani, S.; Zhukova, M.; Koné, N.A.; da Costa, R.R.; Sapountzis, P.; Poulsen, M. Gut microbial compositions mirror caste-specific diets in a major lineage of social insects. Environ. Microbiol. Rep. 2018. [CrossRef] [PubMed]

43. Poulsen, M. Towards an integrated understanding of the consequences of fungus domestication on the fungus-growing termite gut microbiota. Environ. Microbiol. 2015, 17, 2562-2572. [CrossRef]

44. Sands, W.A. The initiation of fungus comb construction in laboratory colonies of Ancistrotermes guineensis (Silvestri). Insectes Soc. 1960, 7, 251-263. [CrossRef]

45. Sieber, R. Establishment of fungus comb in laboratory colonies of Macrotermes michaelseni and Odontotermes montanus (Isoptera, Macrotermitinae). Insectes Soc. 1983, 30, 204-209. [CrossRef]

46. Sieber, R.; Leuthold, R.H. Behavioural elements and their meaning in incipient laboratory colonies of the fungus-growing termite Macrotermes michaelseni (Isoptera: Macrotermitinae). Insectes Soc. 1981, 28, 371-382. [CrossRef]

47. Johnson, R.A.; Thomas, R.J.; Wood, T.G.; Swift, M.J. The inoculation of the fungus comb in newly founded colonies of some species of the Macrotermitinae (Isoptera) from Nigeria. J. Nat. Hist. 1981, 15, 751-756. [CrossRef]

48. Aanen, D.K.; De Fine Licht, H.H.; Debets, A.J.M.; Kerstes, N.A.G.; Hoekstra, R.F.; Boomsma, J.J. High symbiont relatedness stabilizes mutualistic cooperation in fungus-growing termites. Science 2009, 326, 1103-1106. [CrossRef]

49. Darlington, J.P.E.C. The underground passages and storage pits used in foraging by a nest of the termite Macrotermes michaelseni in Kajiado, Kenya. J. Zool. 1982, 198, 237-247. [CrossRef]

50. De Fine Licht, H.H.; Boomsma, J.J.; Aanen, D.K. Asymmetric interaction specificity between two sympatric termites and their fungal symbionts. Ecol. Entomol. 2007. [CrossRef]

51. Nobre, T.; Rouland-Lefèvre, C.; Aanen, D.K. Comparative biology of fungus cultivation in termites and ants. In Biology of Termites: A Modern Synthesis; Bignell, D.E., Roisin, Y., Lo, N., Eds.; Springer: Dordrecht, The Netherlands, 2011; pp. 193-210. ISBN 9789048139767.

52. Rouland-lefèvre, C.; Bignell, D.E. Cultivation of symbiotic fungi by termites of the subfamily Macrotermitinae. In Symbiosis; Seckbach, J., Ed.; Kluwer Academic Publishers: Dordrecht, The Netherlands, 2001; pp. 733-756.

53. Li, H.; Yelle, D.J.; Li, C.; Yang, M.; Ke, J.; Zhang, R.; Liu, Y.; Zhu, N.; Liang, S.; Mo, X.; et al. Lignocellulose pretreatment in a fungus-cultivating termite. Proc. Natl. Acad. Sci. USA 2017, 114, 4709-4714. [CrossRef]

54. De Fine Licht, H.H.; Boomsma, J.J.; Aanen, D.K. Presumptive horizontal symbiont transmission in the fungus-growing termite Macrotermes natalensis. Mol. Ecol. 2006, 64, 2055-2069. [CrossRef] [PubMed]

55. Aanen, D.K. As you reap, so shall you sow: Coupling of harvesting and inoculating stabilizes the mutualism between termites and fungi. Biol. Lett. 2006, 2, 209-212. [CrossRef] [PubMed]

56. Aanen, D.K.; Ros, V.I.D.; De Fine Licht, H.H.; Mitchell, J.; De Beer, Z.W.; Slippers, B.; Rouland-LeFèvre, C.; Boomsma, J.J. Patterns of interaction specificity of fungus-growing termites and Termitomyces symbionts in South Africa. BMC Evol. Biol. 2007, 7, 115. [CrossRef] [PubMed]

57. Da Costa, R.R.; Vreeburg, S.M.E.; Shik, J.Z.; Aanen, D.K.; Poulsen, M. Can interaction specificity in the fungus-farming termite symbiosis be explained by nutritional requirements of the fungal crop? Fungal Ecol. 2018. [CrossRef]

58. Nobre, T.; Aanen, D.K. Fungiculture or termite husbandry? The ruminant hypothesis. Insects 2012, 3, 307-323. [CrossRef] [PubMed]

59. Nobre, T.; Eggleton, P.; Aanen, D.K. Vertical transmission as the key to the colonization of Madagascar by fungus-growing termites? Proc. R. Soc. B Biol. Sci. 2010, 277, 359-365. [CrossRef] 
60. Bright, M.; Bulgheresi, S. A complex journey: Transmission of microbial symbionts. Nat. Rev. Microbiol. 2010, 8, 218-230. [CrossRef]

61. Visser, B.; Le Lann, C.; den Blanken, F.J.; Harvey, J.A.; van Alphen, J.J.M.; Ellers, J. Loss of lipid synthesis as an evolutionary consequence of a parasitic lifestyle. Proc. Natl. Acad. Sci. USA 2010, 11, 8677-8682. [CrossRef]

62. Ellers, J.; Toby Kiers, E.; Currie, C.R.; Mcdonald, B.R.; Visser, B. Ecological interactions drive evolutionary loss of traits. Ecol. Lett. 2012, 15, 1071-1082. [CrossRef] [PubMed]

63. Liu, N.; Zhang, L.; Zhou, H.; Zhang, M.; Yan, X.; Wang, Q.; Long, Y.; Xie, L.; Wang, S.; Huang, Y.; et al. Metagenomic Insights into metabolic capacities of the gut microbiota in a fungus-cultivating termite (Odontotermes yunnanensis). PLoS ONE 2013, 8. [CrossRef] [PubMed]

64. Liu, N.; Yan, X.; Zhang, M.; Xie, L.; Wang, Q.; Huang, Y.; Zhou, X.; Wang, S.; Zhou, Z. Microbiome of fungus-growing termites: A new reservoir for lignocellulase genes. Appl. Environ. Microbiol. 2011, 77, 48-56. [CrossRef] [PubMed]

65. Um, S.; Fraimout, A.; Sapountzis, P.; Oh, D.C.; Poulsen, M. The fungus-growing termite Macrotermes natalensis harbors bacillaene-producing Bacillus sp. that inhibit potentially antagonistic fungi. Sci. Rep. 2013, 3, 3250. [CrossRef] [PubMed]

66. Breznak, J.A. Intestinal microbiota of termites and other xylophagous Insects. Annu. Rev. Microbiol. 1982, 36, 323. [CrossRef]

67. Sapountzis, P.; de Verges, J.; Rousk, K.; Cilliers, M.; Vorster, B.J.; Poulsen, M. Potential for nitrogen fixation in the fungus-growing termite symbiosis. Front. Microbiol. 2016, 7, 1-5. [CrossRef]

68. Hu, H.; da Costa, R.R.; Pilgaard, B.; Busk, P.K.; Schiøtt, M.; Lange, L.; Poulsen, M. Fungiculture in termites is associated with a mycolytic gut bacteria community. mSphere 2019. accepted pending minor revision.

69. Otani, S.; Mikaelyan, A.; Nobre, T.; Hansen, L.H.; Koné, N.A.; Sørensen, S.J.; Aanen, D.K.; Boomsma, J.J.; Brune, A.; Poulsen, M. Identifying the core microbial community in the gut of fungus-growing termites. Mol. Ecol. 2014, 23, 4631-4644. [CrossRef]

70. Hongoh, Y.; Deevong, P.; Inoue, T.; Moriya, S.; Trakulnaleamsai, S.; Ohkuma, M.; Vongkaluang, C.; Noparatnaraporn, N.; Kudo, T. Intra- and interspecific comparisons of bacterial diversity and community structure support coevolution of gut microbiota and termite host. Appl. Environ. Microbiol. 2005, 71, 6590-6599. [CrossRef]

71. Hongoh, Y. Diversity and genomes of uncultured microbial symbionts in the termite gut. Biosci. Biotechnol. Biochem. 2010, 74, 1145-1151. [CrossRef]

72. Dietrich, C.; Köhler, T.; Brune, A. The cockroach origin of the termite gut microbiota: Patterns in bacterial community structure reflect major evolutionary events. Appl. Environ. Microbiol. 2014. [CrossRef] [PubMed]

73. Li, H.; Dietrich, C.; Zhu, N.; Mikaelyan, A.; Ma, B.; Pi, R.; Liu, Y.; Yang, M.; Brune, A.; Mo, J. Age polyethism drives community structure of the bacterial gut microbiota in the fungus-cultivating termite Odontotermes formosanus. Environ. Microbiol. 2016, 18, 1440-1451. [CrossRef] [PubMed]

74. Wood, T.G.; Sands, W.A. The role of termites in ecosystems. In Production Ecology of Ants and Termites; Brian, M.V., Ed.; Cambridge Univ. Press: Cambridge, UK, 1978; pp. 245-292.

75. Buxton, R.D. Termites and the turnover of dead wood in an arid tropical environment. Oecologia 1981, 51, 379-384. [CrossRef] [PubMed]

76. Ashton, L.A.; Griffiths, H.G.; Parr, C.L.; Evans, T.A.; Didham, R.K.; Hasan, F.; Teh, Y.A.; Tin, H.S.; Vairappan, C.S.; Eggleton, P. Termites mitigate the ecosystem-wide effects of drought in tropical rainforest. Science 2019, 177, 174-177. [CrossRef]

77. Nkunika, P.O.Y. A survey of the termite species associated with Eucalyptus plantations in Zambia. Zamb. J. Sci. Technol. 1980, 5, 33-38.

78. Mora, P.; Rouland, C.; Renoux, J. Foraging, nesting and damage caused by Microtermes subhyalinus (Isoptera: Termitidae) in a sugarcane plantation in the Central African Republic. Bull. Entomol. Res. 1996, 86, 387. [CrossRef]

79. Acda, M.N. Foraging populations and territories of the tropical subterranean termite Macrotermes gilvus (Isoptera: Macrotermitinae). Sociobiology 2004, 43, 169-177.

80. Sattar, A.; Misbah, M.; Salihah, Z.; Khatoon, R. Foraging activity of Microtermes unicolor Synder and Odontotermes lokanandi Chatterjee and Thakur (Termitidae, Isoptera) in Peshawar, Pakistan. Suranaree J. Sci. Technol. 2007, 15, 69-74. 
81. Sattar, A.; Naeem, M.; ul-Haq, E. Impact of environmental factors on the population dynamics, density and foraging activities of Odontotermes lokanandi and Microtermes obesi in Islamabad. SpringerPlus 2013, 2, 1-7. [CrossRef]

82. Iqbal, N.; Saeed, S.; Evans, T.A.; Kwon, Y.J. Foraging activity and population estimation of Microtermes mycophagus Desneux (Isoptera: Termitidae: Macrotermitinae) in Multan, Punjab, Pakistan. Entomol. Res. 2015, 45, 51-57. [CrossRef]

83. Lepage, M.G. L'impact des populations récoltantes de Macrotermes michaelseni (Sjostedt) (Isoptera, Macrotermitinae) dans un écosystème semi-aride (Kajiado-Kenya)—I-L'activité de récolte et son déterminisme. Insectes Soc. 1981, 28, 297-308. [CrossRef]

84. Boutton, T.W.; Arshad, M.A.; Tieszen, L.L. Stable isotope analysis of termite food habits in East African grasslands. Oecologia 1983, 59, 1-6. [CrossRef]

85. Dangerfield, J.M.; Schuurman, G. Foraging by fungus-growing termites (Isoptera: Termitidae, Macrotermitinae) in the Okavango Delta, Botswana. J. Trop. Ecol. 2000, 16, 717-731. [CrossRef]

86. Janusz, G.; Pawlik, A.; Sulej, J.; Świderska-Burek, U.; Jarosz-Wilkołazka, A.; Paszczyński, A. Lignin degradation: Microorganisms, enzymes involved, genomes analysis and evolution. FEMS Microbiol. Rev. 2017, 41, 941-962. [CrossRef] [PubMed]

87. Johjima, T.; Taprab, Y.; Noparatnaraporn, N.; Kudo, T.; Ohkuma, M. Large-scale identification of transcripts expressed in a symbiotic fungus (Termitomyces) during plant biomass degradation. Appl. Microbiol. Biotechnol. 2006, 73, 195-203. [CrossRef] [PubMed]

88. Schuurman, G. Foraging and distribution patterns in a termite assemblage dominated by fungus-growing species in semi-arid northern Botswana. J. Trop. Ecol. 2006, 22, 277-287. [CrossRef]

89. N’Dri, A.B.; Gignoux, J.; Konaté, S. Food preferences and foraging strategies of wood-feeding termites in a West African savanna. Curr. Sci. 2018, 114, 186-192. [CrossRef]

90. Coaton, W.; Sheasby, J. Preliminary report on a survey of the termites (Isoptera) of South West Africa. State Mus. 1972, 2, 1-129.

91. Longhurst, C.; Howse, P.E. The use of kairomones by Megaponera foetens (Fab.) (Hymenoptera: Formicidae) in the detection of its termite prey. Anim. Behav. 1978, 2013-2018. [CrossRef]

92. Abe, T. Termite community in the grassland of Kenya with special reference to their feeding habits. In Social Insects and the Environment, Proceedings of the 11th International Congress of IUSSI, Bangalore, India, 5-8 August 1990; International Union for the Study of Social Insects: Bangalore, India, 1990; pp. 207-208.

93. Collins, N.M. The role of termites in the decomposition of wood and leaf litter in the Southern Guinea savanna of Nigeria. Oecologia 1981, 51, 389-399. [CrossRef]

94. Wood, A.T.G.; Johnson, R.A.; Bacchus, S.; Shittu, M.O.; Anderson, J.M. Abundance and Distribution of Termites (Isoptera) in a Riparian Forest in the Southern Guinea Savanna Vegetation Zone of Nigeria. Assoc. Trop. Biol. Conserv. 1982, 14, 25-39. [CrossRef]

95. Eggleton, P.; Bignell, D.E.; Sands, W.A.; Waite, B.; Wood, T.G.; Lawton, J.H. The species richness of termites (Isoptera) under differing levels of forest disturbance in the Mbalmayo Forest Reserve, southern Cameroon. J. Trop. Ecol. 1995, 11, 85-98. [CrossRef]

96. Lee, C.Y.; Ngee, P.S.; Lee, L.C. Foraging populations and territories of a mound-building subterranean termite, Microtermes pakistanicus (Isoptera: Macrotermitinae). Sociobiology 2003, 41, 307-316.

97. Jouquet, P.; Boulain, N.; Gignoux, J.; Lepage, M. Association between subterranean termites and grasses in a West African savanna: Spatial pattern analysis shows a significant role for Odontotermes n. pauperans. Appl. Soil Ecol. 2004, 27, 99-107. [CrossRef]

98. Al-Hemyari, A.A. Factors affecting foraging activity of Microtermes yemenensis (Isoptera: Termitidae). Ann. Agric. Sci. 1994, 32, 987-995.

99. Rouland, C.; Lepage, M.; Chotte, J.L.; Diouf, M.; Ndiaye, D.; Ndiaye, S.; Seugé, C.; Brauman, A. Experimental manipulation of termites (Isoptera, Macrotermitinae) foraging patterns in a Sahelo-Sudanese savanna: Effect of litter quality. Insectes Soc. 2003, 50, 309-316. [CrossRef]

100. Schuurman, G. Decomposition rates and termite assemblage composition in semiarid Africa. Ecology 2005, 86, 1236-1249. [CrossRef]

101. Mitchell, B.L. Report on a survey of the termites of Zimbabwe. Occas. Pap. Natl. Mus. South. Rhod. 1980, 6, 187-323. 
102. Mugerwa, S.; Nyangito, M.; Mpairwe, D.; Nderitu, J. Effect of biotic and abiotic factors on composition and foraging intensity of subterranean termites. Afr. J. Environ. Sci. Technol. 2011, 5, 579-588. [CrossRef]

103. Ouédraogo, E.; Mando, A.; Brussaard, L. Soil macrofaunal-mediated organic resource disappearance in semi-arid West Africa. Appl. Soil Ecol. 2004, 27, 259-267. [CrossRef]

104. Sands, W.A. Observations on termites destructive to trees and crops. North. Reg. Min. Agric. Samaru Res. Bull. 1962, 26, 1-14.

105. Korb, J.; Linsenmair, K.E. Evaluation of predation risk in the collectively foraging termite Macrotermes bellicosus. Insectes Soc. 2002, 49, 264-269. [CrossRef]

106. Johjima, T.; Inoue, T.; Ohkuma, M.; Noparatnaraporn, N.; Kudo, T. Chemical Analysis of Food Processing by the Fungus-Growing Termite Macrotermes gilvus. Sociobiology 2003, 42, 815-824.

107. Bathellier, J. Contribution à l'etude systematique et biologique des Termites de l'Indochine. Faune Colon. Fran 1927, 1, 125-365.

108. Kalshoven, L.G.E. Observations on Macrotermes gilvus Holmgr. In Java-3 Accumulations of finely cut vegetable matter in the nests. Insectes Soc. 1956, 3, 455-461. [CrossRef]

109. Santoso, E.T.H. Pest and disease control of timber estates in East Kalimantan. J. Res. Dev. 1991, 7, 14-17.

110. Lepage, M. Foraging and food consumption of Macrotermes subhyalinus. In Proceedings of the VIIIth International Congress IUSSI, Wageningen, The Netherlands, 5-9 September 1977; pp. 249-252.

111. Lepage, M. L' impacte des populations récoltantes des Macrotermes michaelseni (Sjostedt) (Isoptera: Macrotermitinae) dans un écosystème semi-aride (Kaijaido-Kenya) II. Nourriture récoltée, comparison avec les grands herbivores. Insectes Soc. 1981, 28, 309-319. [CrossRef]

112. Grassé, P.P.; Noirot, C. La transmission des flagellés symbiotiques et les aliments des termites. Bull. Biol. Fr. Belg. 1945, 79, 273-292.

113. Meyer, V.W.; Crewe, R.M.; Braack, L.E.O. Estimates of food consumption by the fungus-growing termite Macrotermes natalensis in a South African savanna-woodland. S. Afr. J. Sci. 2003, 99, 207-208.

114. Lepage, M. L'impact des populations récoltantes de Macrotermes michaelseni (Sjöstedt) (Isoptera: Macrotermitinae) dans un écosystème semi-aride (Kajiado-Kenya) II-La nourriture récoltée, comparaison avec les grands herbivores. Insectes Soc. 1978, 28, 309-319.

115. Burchard, I. On the removal of herbivore dung by Odontotermes spp. in Africa. Sociobiology 1989, 15, 261.

116. Kemp, P.B. The termites of north-eastern Tanganyika: Their distribution and biology. Bull. Entomol. Res. 1955, 46, 112-135. [CrossRef]

117. Soleymaninejadian, E.; Ji, B.Z.; Liu, S.W.; Yang, J.J.; Wang, H.J.; Ding, F. Polyethism in Odontotermes formosanus Shiraki. Int. J. Biol. Med. Res. 2014, 5, 4231-4238.

118. Chiu, C.I.; Yeh, H.T.; Li, P.L.; Kuo, C.Y.; Tsai, M.J.; Li, H.F. Foraging Phenology of the Fungus-Growing Termite Odontotermes formosanus (Blattodea: Termitidae). Environ. Entomol. 2018, 47, 1509-1516. [CrossRef] [PubMed]

119. Malik, M.U.; Javed, H.; Ayyaz, M. Evaluation of Different Groundnut Arachis hypogea L. Cultivars Against Termites, Odontotermes obesus (Rambur) in Rawalpindi, Pakistan. Turk. J. Agric. Food Sci. Technol. 2015, 3, 448-452. [CrossRef]

120. Wheatley, P.E.; Crowe, T.J. Pest Handbook: The Recognition and Control of the More Important Pests of Agriculture in Kenya; Government Printer: Nairobi, Kenya, 1967.

121. Benjamen, D.M. Insects and mites on tea in Africa and adjacent islands. East Afr. Agric. J. 1968, 33, $345-357$. [CrossRef]

122. Togola, A.; Kotoklo, E.A.; Nwilene, F.E.; Amevoin, K.; Glitho, I.A.; Oyetunji, O.E.; Kiepe, P. Specific diversity and damage of termites on upland rice in Benin. J. Entomol. 2012, 9, 352-360. [CrossRef]

123. Sands, W.A. Termites as pests of tropical food crops. Pest Artic. News Summ. 1973, 19, 167-177. [CrossRef]

124. Dibangou, V.; Mora, P.; Celini, L.; Rouland-LeFèvre, C. Spatial distribution and density of fungus-growing termite Pseudacanthotermes militaris (Isoptera: Macrotermitinae) in the Congo Republic. Asian J. Biol. Sci. 2012, 5, 406-416. [CrossRef]

125. Nair, K.S.S. Tropical Forest Insect Pests: Ecology, Impact, and Management; Cambridge University Press: Cambridge, UK, 2007.

126. Taprab, Y.; Johjima, T.; Maeda, Y.; Moriya, S.; Trakulnaleamsai, S.; Noparatnaraporn, N.; Ohkuma, M.; Kudo, T. Symbiotic fungi produce laccases potentially involved in phenol degradation in fungus combs of fungus-growing termites in Thailand. Appl. Environ. Microbiol. 2005, 71, 7696-7704. [CrossRef] 
127. Geier, M.S.; Filley, T.R.; Hatcher, P.G.; Hoover, K.; Carlson, J.E.; Jimenez-Gasco, M.M.; Nakagawa-Izumi, A.; Sleighter, R.L.; Tien, M. Lignin degradation in wood-feeding insects. Proc. Natl. Acad. Sci. USA 2008, 105, 12932-12937. [CrossRef]

128. Tarmadi, D.; Tobimatsu, Y.; Yamamura, M.; Miyamoto, T.; Miyagawa, Y.; Umezawa, T.; Yoshimura, T. NMR studies on lignocellulose deconstructions in the digestive system of the lower termite Coptotermes formosanus Shiraki. Sci. Rep. 2018, 8, 1-9. [CrossRef] [PubMed]

129. Liu, N.; Li, H.; Chevrette, M.G.; Zhang, L.; Cao, L.; Zhou, H.; Zhou, X.; Zhou, Z.; Pope, P.B.; Currie, C.R.; et al. Functional metagenomics reveals abundant polysaccharide-degrading gene clusters and cellobiose utilization pathways within gut microbiota of a wood-feeding higher termite. ISME J. 2019, 13, 104-117. [CrossRef] [PubMed]

130. Tokuda, G.; Mikaelyan, A.; Fukui, C.; Matsuura, Y.; Watanabe, H.; Fujishima, M.; Brune, A. Fiber-associated spirochetes are major agents of hemicellulose degradation in the hindgut of wood-feeding higher termites. Proc. Natl. Acad. Sci. USA 2018, 115, 201810550. [CrossRef] [PubMed]

131. Busk, P.K.; Pilgaard, B.; Lezyk, M.J.; Meyer, A.S.; Lange, L. Homology to peptide pattern for annotation of carbohydrate-active enzymes and prediction of function. BMC Bioinform. 2017, 18, 214. [CrossRef] [PubMed]

132. Busk, P.K.; Lange, L. Function-based classification of carbohydrate-active enzymes by recognition of short, conserved peptide motifs. Appl. Environ. Microbiol. 2013, 79, 3380-3391. [CrossRef] [PubMed]

133. Thomsen, P.F.; Willerslev, E. Environmental DNA-An emerging tool in conservation for monitoring past and present biodiversity. Biol. Conserv. 2015, 183, 4-18. [CrossRef]

134. De Fine Licht, H.H.; Schiøtt, M.; Mueller, U.G.; Boomsma, J.J. Evolutionary transitions in enzyme activity of ant fungus gardens. Evolution 2010, 64, 2055-2069. [CrossRef]

135. Kračun, S.K.; Schückel, J.; Westereng, B.; Hygesen, L.G.; Monrad, R.N.; Eijsink, V.G.; Willats, W.G.T. A new generation of versatile chromogenic substrates for high-throughput analysis of biomass-degrading enzymes. Biotechnol. Biofuels 2018, 8, 70. [CrossRef]

136. Sahadevan, L.D.M.; Misra, C.S.; Thankamani, V. Characterization of lignin-degrading enzymes (LDEs) from a dimorphic novel fungus and identification of products of enzymatic breakdown of lignin. 3 Biotech 2016, 6, 1-16. [CrossRef]

137. Barbehenn, R.; Dodick, T.; Poopat, U.; Spencer, B. Fenton-type reactions and iron concentrations in the midgut fluids of tree-feeding caterpillars. Arch. Insect Biochem. Physiol. 2005, 60, 32-43. [CrossRef] [PubMed]

138. Franco Cairo, J.P.L.; Carazzolle, M.F.; Leonardo, F.C.; Mofatto, L.S.; Brenelli, L.B.; Gonçalves, T.A.; Uchima, C.A.; Domingues, R.R.; Alvarez, T.M.; Tramontina, R.; et al. Expanding the knowledge on lignocellulolytic and redox enzymes of worker and soldier castes from the lower termite Coptotermes gestroi. Front. Microbiol. 2016, 7, 1518. [CrossRef] [PubMed]

(C) 2019 by the authors. Licensee MDPI, Basel, Switzerland. This article is an open access article distributed under the terms and conditions of the Creative Commons Attribution (CC BY) license (http://creativecommons.org/licenses/by/4.0/). 